\title{
Euglossine bees (Hymenoptera, Apidae) in a remnant of Atlantic Forest in Paraná State, Brazil
}

\author{
Silvia H. Sofia ${ }^{1}$; Aline M. dos $\operatorname{Santos}^{2} \&$ Carlos R. M. da Silva ${ }^{1}$ \\ 1. Depto de Biologia Geral, Centro de Ciências Biológicas, Universidade Estadual de Londrina, Caixa Postal 6001, 86051-990, \\ Londrina, PR, Brasil. \\ 2. Departamento de Genética, Bloco A, Faculdade de Medicina de Ribeirão Preto, Universidade de São Paulo, Av. Bandeirantes, \\ 3900, 14049-900, Ribeirão Preto, SP, Brasil.
}

\begin{abstract}
Species composition, relative abundance, seasonal changes in the species abundance and scent association of male Euglossini collected in a semi-deciduous forest fragment in the north of the State of Paraná, southern Brazil, were recorded. Euglossine males were collected twice a month, for twelve months, from 8:00 am to 3:00 pm. The scents eucalyptol, eugenol, vanillin, methyl salicylate and benzyl acetate were used as baits. A total of 434 males distributed among 3 genera and 9 species were attracted to the chemical baits. Eufriesea violacea (Blanchard, 1840) (49.8\%), Eulaema nigrita Lepeletier, 1841 (23.0\%) and Euglossa pleosticta Dressler, 1982 (13.8\%) were dominant in number of individuals. Among the non-dominant species, Euglossa fimbriata Rebêlo \& Moure, 1995 was more common (9.0\%), followed by E. cordata (L., 1758) (1.8\%), E. truncata Rebêlo \& Moure, 1995 (1.4\%), E. melanotricha Moure, 1967 (0.7\%), E. townsendi Cockerell, 1904 (0.23\%) and Eufriesea auriceps Friese, 1899 (0.23\%). In general, bees were more abundant in warm-wet season (September-March). Eufriesea violacea was the most seasonal species, showing activity through the warm-wet season, from October to February. Eucalyptol was the most attractive fragrance, which was responsible for $92.6 \%$ of all visits by euglossine bees.
\end{abstract}

KEYWORDS. Euglossinae, Euglossini, forest fragment, orchid bees, scent baits.

\section{INTRODUCTION}

Euglossine bees are important pollinators of many families of angiosperms (ZuCCHI et al., 1969; JANZEN, 1971; Dressler, 1982; PeArson \& Dressler, 1985). Both female and male euglossine bees often fly long distances between dispersed resources, making them especially significant in cross-pollination of widely scattered plant species in neotropical forests (DRESSLER, 1968a; JANZEN, 1971; WiLliams \& Dodson, 1972). They are commonly known as orchid bees because the males are frequently found visiting orchids to collect floral chemical fragrances (DressLer, 1968b, 1982), which they probably use as precursors to sex pheromones (Dodson et al., 1969; Williams \& WitTHEN, 1983; BuChMANn \& NabHam, 1996). The orchid-euglossine bee relationship provides an excellent example of a highly taxon-dependent pollination system, since a wide array of neotropical orchid species are pollinated solely by euglossine bees (DRESSLER, 1968b; ACKERMAn, 1983a; Williams \& WhitTen, 1983; NefF \& Simpson, 1993).

Purified components of floral fragrances and some synthetic chemicals can be used to attract male euglossines and thereby census them (Dodson et al., 1969; Williams \& Dodson, 1972; Dressler, 1982). The number of males found at baits seems to reflect patterns of emergence of these bees and is correlated with frequency of visits to natural sources, so censuses may indicate actual bee abundance (ACKERMAN, 1983b). The use of chemical baits as attractants has also made possible to estimate geographical distribution of many species (Dodson et al., 1969; Rebêlo \& Silva, 1999). Chemical baiting techniques have been widely used to study different aspects of euglossine communities in Costa Rica
(JANZEN et al., 1982; RoubiK, 2001), Panama (Ricklefs et al., 1969) and Peru (PEARson \& DressLer, 1985). In Brazil, euglossine bees studies have been developed primarily in Amazonian Forest (BeCKer et al., 1991; OlIVEIRA, 1999; Silva \& RebêLo, 2002) and in Atlantic Rainforest remnants (Peruquetti et al., 1999; Bezerra \& Martins, 2001; Santos $\&$ SOFIA, 2002).

The Atlantic Rainforest is one the most endangered forests, which has been severely destroyed after centuries of deforestation. Nowadays only about 5 to $12 \%$ of the original forest remains as isolated forest remnants scattered throughout a landscape dominated by agricultural uses (BRown \& BRown, 1992; ChiARELlO, 1999). Recently the Parque Estadual Mata dos Godoy, an Atlantic Forest remnant, in northern region of Paraná State, was included by the Brazilian government as a priority area for surveys of invertebrate fauna, considering its extreme importance to conservation and management of this biome (BRASIL, 2000). The purpose of this work was to study the community of euglossine fauna of this State Park in southern Brazil.

\section{MATERIAL AND METHODS}

The Parque Estadual Mata dos Godoy (MG) is a forest fragment of 680 ha, surrounded by cropped area, located in the district of Londrina city (23\% $27^{\prime} \mathrm{S}$ and $51^{\circ} 15^{\prime} \mathrm{W}$ ), north of Paraná State, southern Brazil (fig. 1). The vegetation of the Park is classified as semi-deciduous subtropical forest (ChAGAS-E-Silva \& SOARES-SilVA, 2000; TORREZAN, 2002), which represents an associated ecosystem of Atlantic Rainforest (FERnANDES \& BEZERRA, 1990).

The local climate is classified as Cfa, humid 


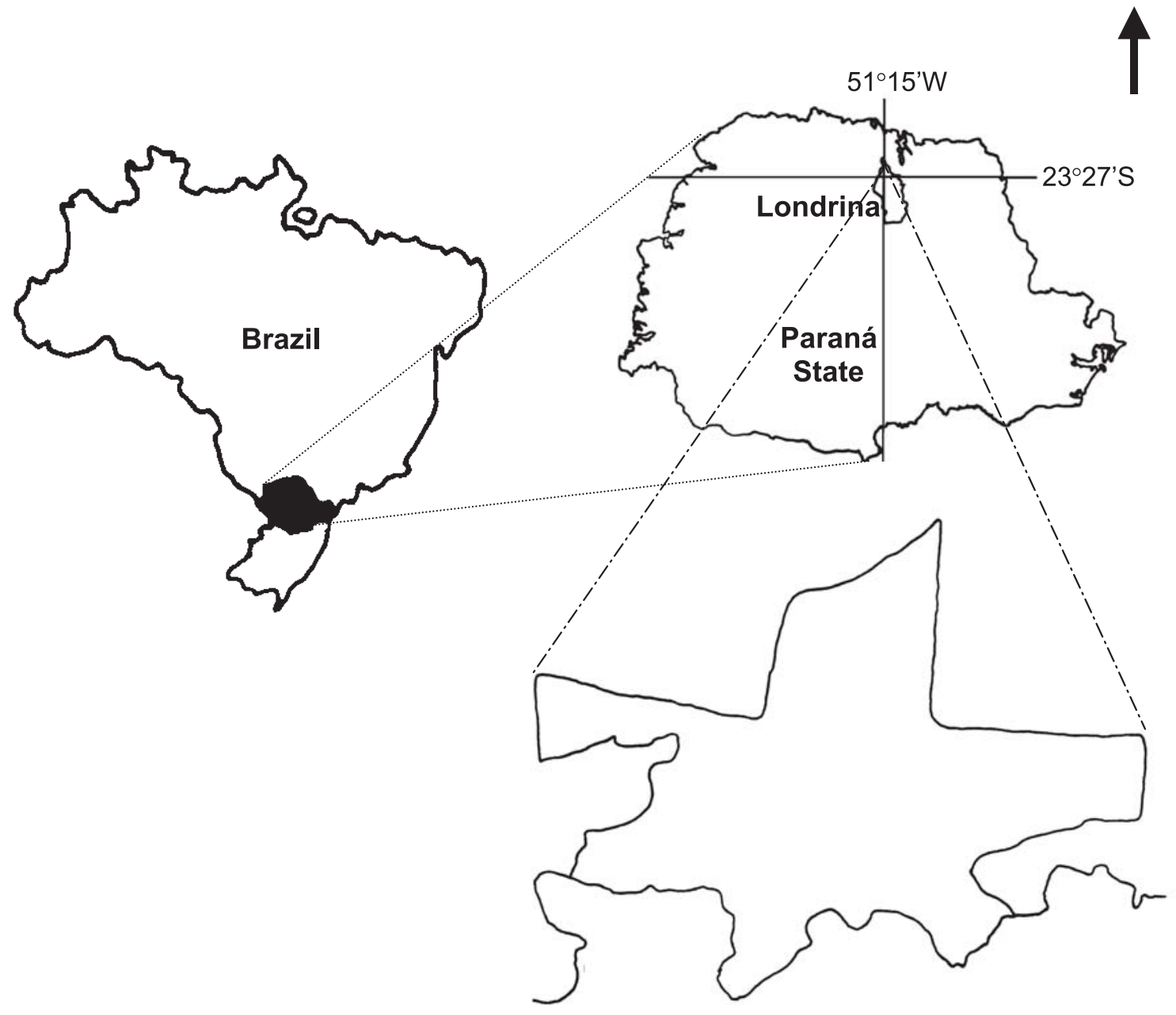

Fig. 1. Localization of the Parque Estadual Mata dos Godoy in Paraná State, southern Brazil.

subtropical with warm summer (IAPAR, 1994; MENDONÇA, 2000), rain is distributed in all seasons, with a decline in rainfall in the winter (June, July and August). From 1977 through 2000, mean annual rainfall, temperature and relative humidity registered for the region were: 1626.0 $\mathrm{mm}, 20.9^{\circ} \mathrm{C}$ and $70.9 \%$, respectively (data provided by IAPAR, Instituto Agronômico do Paraná).

The sampling method was based on ReBÊLo \& Garófalo (1991), with some modifications. From November 1998 through October 1999, twice a month, male euglossine bees were collected with an entomological net when they arriving at chemical baits. Baits consisted of little balls (diameter $=5 \mathrm{~cm}$ ) of absorbent paper each saturated with one of five different chemicals (benzyl acetate, eugenol, eucalyptol, methyl salicylate and vanillin), placed at the edge of forest, about $2.0 \mathrm{~m}$ apart and $1.5 \mathrm{~m}$ above the ground. Baits were available from 8:00 am until 3:00 pm, and were constantly monitored by the collector. To make the census more effective, clear days were chosen whenever possible (JANZEN et al., 1982). All chemicals were replenished on the baits every hour to prevent losses due to their volatility.
In laboratory, the specimens were identified and voucher specimens of all species of bees are deposited at the Museu de Zoologia, Universidade Estadual de Londrina (UEL).

Air temperature and relative humidity were measured every hour during the collections using a hygrometer with dry and wet bulbs hung $1.2 \mathrm{~m}$ above the ground. Rainfall, temperature and relative humidity for the study area were obtained from IAPAR.

Abundance was calculated from the total number of individuals attracted to all chemical baits throughout the year. Seasonal abundance was estimated as the number of bees collected each month. The dominant species was determined as described by KaTô et al. (1952). Faunal diversity was estimated by means of the Shannon's index (H') and species evenness by means of Pielou's index (J') (Ludwig \& REYNOLDS, 1988). Sorensen's similarity coefficient (LAROCA, 1995) was used to compare the results of this study with data reported in other works (REBÊLO \& GARÓFALO, 1991, 1997; GARÓFALO et al., 1998; JESUS \& GARÓFALO, 2000) concerning euglossine bees in similar semi-deciduous forests. Chi-square test ( 2 x 2) was employed to analyze bee preference for fragrances. 
Correlations between biotic (number of individuals and species of bees captured monthly) and abiotic (temperature, humidity and rainfall) data were tested for significance using Spearman's rank correlation coefficient $\left(r_{s}\right)$ (Ludwig \& REYNOLDS, 1988; ZaR, 1996). Values were considered different where $\mathrm{P}<0.05$.

\section{RESULTS}

A total of 434 males of 9 species, in three genera (Euglossa, Eufriesea and Eulaema), were attracted to three of the five chemical baits (tab. I). The most attractive scent was eucalyptol $\left(x^{2}=627.47, \mathrm{df}=1, \mathrm{P}<0.0001\right)$, which attracted $92.6 \%$ of the total visits and 9 species of bees. Vanillin was the second most attractive fragrance (7.1\%) and was visited by Eufriesea violacea (Blanchard, 1840), Eulaema nigrita Lepeletier, 1841 and Euglossa pleosticta Dressler, 1982. No bees visited benzyl acetate or eugenol.

Three species were dominant: Eufriesea violacea $(\mathrm{n}=216$ individuals), Eulaema nigrita (100) and Euglossa pleosticta (60), representing $86.6 \%$ of the total bees sampled. The percentage of the remaining species visited baits ranged from 9 to $0.23 \%$ (tab. I).

The euglossine faunal diversity $\left(\mathrm{H}^{\prime}\right)$ and species evenness ( $\left.\mathrm{J}^{\prime}\right)$ in MG were 1.37 and 0.62 , respectively.

The highest rainfall $(699.3 \mathrm{~mm})$ occurred during December, January and February. June had a high rainfall (135.7mm) and August was the driest month (fig. 2). The highest relative humidity occurred in January, February and June, and varied from 79.2 to $81.4 \%$.

The highest mean temperatures occurred from November to March, and the lowest from May to July (fig. 3). The bees were most abundant during the warmest and rainiest period (November to March) when $69.1 \%$ of the total males were captured (fig. 2). A clear reduction in bee activity occurred during the colder months (April to August) when the mean temperature was $18.2^{\circ} \mathrm{C}$. No bees were attracted to baits in May or June, the coldest months of the period (figs. 2,3). There was a significant correlation between bee abundance and mean temperature $\left(r_{s}=0.668\right.$, $\mathrm{n}=12, \mathrm{P}<0.05)$.

The number of species ranged from zero (May and June) to eight (October). Monthly bee abundance and
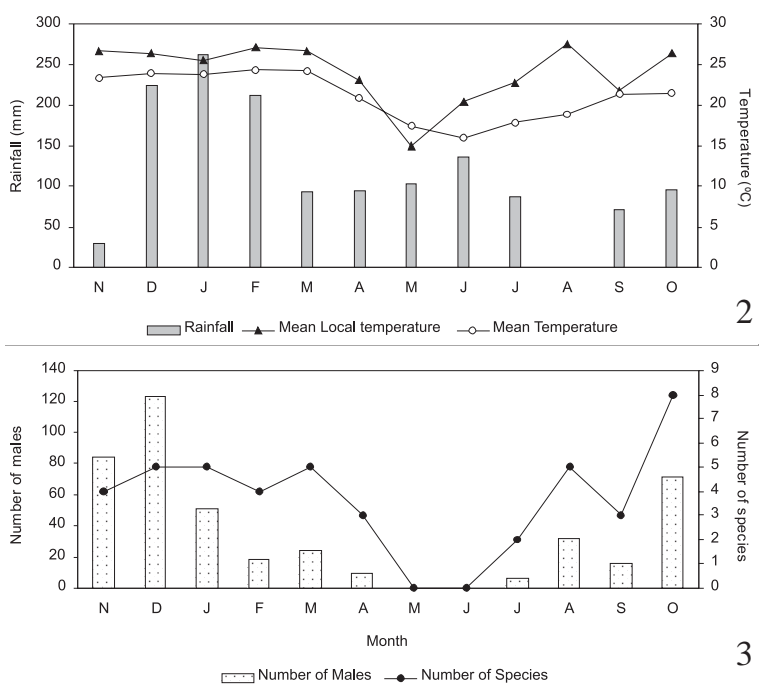

Figs. 2, 3. Climatic diagram for the Parque Estadual Mata dos Godoy, Londrina, PR, throughout November/1998 to October/ 1999: 2, rainfall $(\mathrm{mm})$, mean temperature and mean local temperature $\left({ }^{\circ} \mathrm{C}\right) ; 3$, monthly abundance of males and species attracted to scent baits.

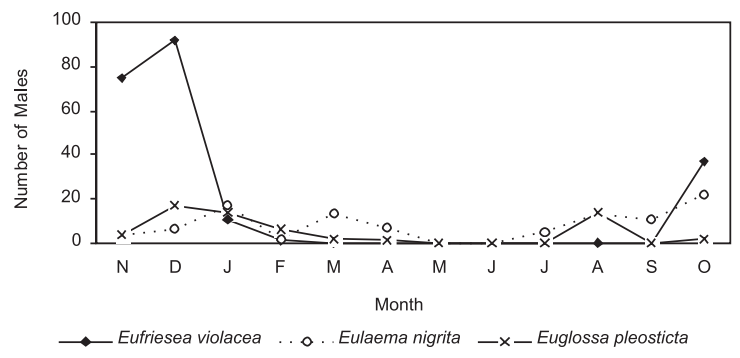

Fig. 4. Monthly abundance of the three most frequent euglossine bee species surveyed at Parque Estadual Mata dos Godoy, from November/1998 to October/1999.

species richness were highly correlated $\left(r_{s}=0.86, \mathrm{n}=12\right.$, $\mathrm{P}<0.0001)$. During the period from September to March (warm-wet season) and April to August (cold-dry season)

Table I. Number and percentage of males of Euglossinae bees captured at each chemical bait visited by bees, in the Parque Estadual Mata dos Godoy, Londrina, from November/1998 to October/1999 (N, number of individuals).

\begin{tabular}{|c|c|c|c|c|c|c|c|c|}
\hline \multirow[t]{2}{*}{ Species } & \multicolumn{2}{|c|}{ Eucalyptol } & \multicolumn{2}{|c|}{ Vanillin } & \multicolumn{2}{|c|}{ Methyl Salicylate } & \multirow[t]{2}{*}{ Total males } & \multirow[t]{2}{*}{$\%$ males } \\
\hline & $\mathrm{N}$ & $\%$ & $\mathrm{~N}$ & $\%$ & $\mathrm{~N}$ & $\%$ & & \\
\hline Eufriesea violacea (Blanchard, 1840) & 186 & 86.1 & 29 & 13.4 & 1 & 0.5 & 216 & 49.80 \\
\hline E. auriceps Friese, 1899 & 1 & 100.0 & 0 & 0.0 & 0 & 0 & 1 & 0.23 \\
\hline Eulaema nigrita Lepeletier, 1841 & 99 & 99.0 & 1 & 1.0 & 0 & 0 & 100 & 23.00 \\
\hline Euglossa pleosticta Dressler, 1982 & 59 & 98.3 & 1 & 1.7 & 0 & 0 & 60 & 13.80 \\
\hline E. fimbriata Rebêlo \& Moure, 1995 & 39 & 100.0 & 0 & 0.0 & 0 & 0 & 39 & 9.00 \\
\hline E. cordata (Linnaeus, 1758) & 8 & 100.0 & 0 & 0.0 & 0 & 0 & 8 & 1.84 \\
\hline E. truncata Rebêlo \& Moure, 1995 & 6 & 100.0 & 0 & 0.0 & 0 & 0 & 6 & 1.40 \\
\hline E. melanotricha Moure, 1967 & 3 & 100.0 & 0 & 0.0 & 0 & 0 & 3 & 0.70 \\
\hline E. townsendi Cockerell, 1904 & 1 & 100.0 & 0 & 0.0 & 0 & 0 & 1 & 0.23 \\
\hline Individuals & 402 & 92.6 & 31 & 7.2 & 1 & 0.2 & 434 & 100.00 \\
\hline Species & 9 & 100.0 & 3 & 33.3 & 1 & 11.1 & 9 & - \\
\hline
\end{tabular}


it was found all nine species were active during the warmwet season, but only five in the cold-dry season (fig. 3).

Among the four most abundant species (tab. I), only E. violacea was restricted to the warm-wet season, while Eulaema nigrita, Euglossa pleosticta and E. fimbriata Rebêlo \& Moure, 1995 were active in both seasons (fig. 4). Of these species, Eufriesea violacea was both the most abundant and the most seasonal species (fig. 4).

\section{DISCUSSION}

The general pattern of bee abundance in MG was similar to those in other studies, showing that most species are represented by a small number of individuals, while a small number of species are represented by a large number of individuals (RICKLEFS et al., 1969; JANZEN et al., 1982; ACKERMAN, 1983b; OliveIRA \& CAMPOS, 1995; RebÊlo \& Garófalo, 1997; Silva \& RebÊlo, 2002). A low frequency of Eufriesea auriceps Friese 1899, Euglossa townsendi Cockerell, 1904 and E. melanotricha Moure, 1967 was also verified by other authors (REBÊLO \& GARÓFALO, 1991; NEVES \& VianA, 1997; REBÊLO \& CABRAL, 1997; GARÓFAlO et al., 1998) and could be related to the low association of these euglossine species to the scent used as baits (REBÊLo \& GARÓFALO, 1991), since many studies revealed that not all euglossine species present in a habitat were attracted to scent baits (ACKERMAN, 1983b; PeArson \& Dressler, 1985; Rebêlo \& Garófalo, 1991; BEZERRA \& MARTINS, 2001). Also the low number of some those euglossine species could be reflecting the structure of local populations (REBÊLO \& GARÓFALO, 1991).

The present results suggest that some euglossine species in semi-deciduous forest ecosystems have a more constant pattern of abundance and dominance than others. Few studies in neotropical semi-deciduous forests such as MG reported the remarkable abundance of $E$. violacea males found in the MG community (GARÓFALO et al., 1998; JESUS \& GARÓFALO, 2000), while three abundant species in MG (Eulaema nigrita, Euglossa pleosticta and $E$. fimbriata) were also frequent in all studies performed in semi-deciduous forest fragments in southeastern Brazil (REBÊLO \& GARÓFALO, 1991, 1997; GARÓFALO et al., 1998; JESUS \& GARÓFALO, 2000). The values of species diversity $\left(\mathrm{H}^{\prime}=1.37\right)$ and evenness $\left(\mathrm{J}^{\prime}=0.62\right)$ found at MG reflected the dominance of Eufriesea violacea.

Plant communities that are widely separated geographically, but show similar physiognomic characteristics, tend to have similar bee communities (MoldenKe, 1975). All the species attracted to baits at MG have been found in different semi-deciduous forest remnants in southeastern Brazil (REBÊLO \& GARÓFALO, 1991, 1997; Garófalo et al., 1998; Jesus \& Garófalo, 2000), suggesting that the euglossine fauna of Brazilian semideciduous forests are very similar. The comparison between euglossine fauna of MG and others remnants in southeastern Brazil, using Sorensen's coefficient, showed values of similarity ranging from $63.2 \%$ to $94.7 \%$, supporting Moldenke's idea.

The effectiveness of cineole, a relative scent of eucalyptol, in attracting euglossine males is well known
(DRESSler, 1982; ACKERMAN, 1989; RebÊlo \& GARÓFAlO, 1991; Morato et al., 1992; Silva \& RebÊlo, 2002). In contrast, eugenol and methyl salycilate, which were very attractive to male euglossine in other sites, were poor attractants at Godoy Forest. Geographical differences in fragrance preference are common (PEARSON \& DRESSLER, 1985; Ackerman, 1989). At two sites in Panama, ACKERMAN (1989) found that seven out of eleven euglossine species showed seasonal differences in fragrance preference. He suggested that geographic variation in fragrance choice may be due to age or genetic differences among populations, or differences in fragrance resource availability.

The larger number of euglossine bees visiting the baits during the warm-wet season was in line with other researches on euglossine bee communities in Brazil (Rebêlo \& Garófalo, 1991; Oliveira \& Campos, 1995; REBÊlo \& GARÓFAlO, 1997; GARÓFAlo et al., 1998; OliveIRA, 1999; SILVA \& REBÊLO, 1999, 2002).

Climatic parameters certainly determine the occurrence of some euglossine bees species in the subtropics, while in the tropics, rainfall plays a marked role in the incidence of all euglossine bees species (SILVA \& ReBÊLO, 2002). In this study it was observed that euglossine bees of MG showed a similar pattern of activity to other semi-deciduous forest (REBÊLO \& GARÓFALO, 1991, 1997; GaróFAlo et al., 1998; Jesus \& GaróFAlo, 2000), that is, bees are more active during the rainy-wet season.

As mentioned, sampling was performed preferentially on sunny days, when weather conditions were more suited to bee activity. Hence, the measured local temperature was frequently higher than the mean monthly temperature provided by IAPAR, except in May and September (fig. 2). The high mean temperature during the sampling days $\left(27.5^{\circ} \mathrm{C}\right)$ may explain the increased bee abundance in August (figs. 2, 3). Conversely, the low number of males captured in February might be due to the unfavorable weather conditions during the sampling days or to the rainy period that immediately preceded the samplings in that month (fig. 2).

Several species of Eufriesea Cockerell, 1908 exhibit a seasonal pattern of activity with a very short active period (from 2 to 4 months) during the year, usually in the rainy season (DRESSLER, 1982; JANZEN et al., 1982; ACKerman, 1983b; RoubiK \& ACKERMAn, 1987). Such bees spend most of the annual cycle as diapausing prepupae (DRESSLER, 1982). The high seasonal variation observed for E. violacea in $\mathrm{MG}$ has previously been described (Wittmann et al., 1989; RebÊlo \& Garófalo, 1991; Peruquetti \& Campos, 1997; Rebêlo \& Garófalo, 1997; Garófalo et al., 1998; Jesus \& Garófalo, 2000). This species has one generation a year (WITTMANN et al., 1989), and males usually emerge in September and females after October (Peruquetti \& CAmpos, 1997). Then, a high abundance of these bees is expected from October to December. Besides, the high frequency of males might be related to a high reproduction investment to increase mating success, given that this species shows a remarkable seasonal behavior, with a short period of activity throughout the year.

Populations of some euglossine bees species may remain active but reduced in size and locally restricted at 
certain times of the year. Such seasonal fluctuations in species abundance are probably caused by local nesting and emergence patterns of the bees (ACKERMAN, 1983a; RebêLo \& GaróFAlo, 1991). The long active period of $E$. nigrita during the year (fig. 4) confirms the pattern of activity not strongly seasonal of these bees in semideciduous forests described elsewhere (REBÊLO \& GARÓFALO, 1991, 1997; GARóFALO et al., 1998).

Population studies of bees allow graphic understanding of trends in pollinator abundance and what kinds of abundance variability can be expected, but long-term and continuous studies about bee populations are still scant. However, they are needed for meaningful insights on pollinator population shifts in nature (RouBIK, 2001).

This is the first characterization of a euglossine bees community in a remnant of Atlantic Forest in northern Paraná State. It is now necessary long-term studies to better understand their seasonal patterns, annual fluctuations and population stability (MORATO, 1998; ROUBIK, 2001).

Acknowledgments. To the biologist J. C. Serrano (Universidade de São Paulo, USP, Ribeirão Preto) for his valuable help in bee identification and to Dr. C. A. Garófalo (USP, Ribeirão Preto) for criticizing the manuscript, to IAP - Londrina, for permission to collect bees and to IAPAR for providing climatic data. This study was supported by CPG-UEL and CNPq (fellowship to C. R. M. Silva).

\section{REFERENCES}

Ackerman, J. D. 1983a. Specificity and mutual dependency of the orchid-euglossine bee interaction. Biological Journal of Linnaean Society, London, 20(3):301-314.

1983b. Diversity and seasonality of male euglossine bees (Hymenoptera: Apidae) in Central Panama. Ecology, Ithaca, 64(2):274-283.

1989. Geographic and seasonal variation in fragrance choices and preferences of male euglossine bees. Biotropica, St. Louis, 21(4):340-347.

Becker, P.; Moure, J. S. \& Peralta, F. J .A. 1991. More about Euglossine bees in Amazonian forest fragments. Biotropica, St. Louis, 23(4b):586-591.

Bezerra, C. P. \& Martins, C. F. 2001. Diversidade de Euglossinae (Hymenoptera, Apidae) em dois fragmentos de Mata Atlântica localizados na região urbana de João Pessoa, Paraíba, Brasil. Revista Brasileira de Zoologia, Curitiba, 18(3):823-835.

Brasil. Ministério do Meio Ambiente. 2000. Avaliação e ações prioritárias para a conservação da biodiversidade da Mata Atlântica e Campos Sulinos. Brasília, Fund. SOS Mata Atlântica, Fund. Biodiversitas, IPE, SEMA-SP, SEMAD/IEF, MMA/SBF. 40p.

Brown, K. S. \& Brown, G. G. 1992. Habitat alteration and species loss in Brazilian forests. In: Whitmore, T. C. \& SAYer, J. A. ed. Tropical deforestation and species extinction. London, Chapman \& Hall. p.119-142.

Buchmann, S. L. \& Nabham, G. P. 1996. Pollinators: waiting for the bait to pervade the air. In: The forgotten pollinators. Washington, Island. p.47-64.

Chagas-e-Silva, F. \& Soares-Silva, L. H. 2000. Arboreal flora of Godoy Forest State Park, Londrina, PR, Brazil. Edinburg Journal of Botany, Cambridge, 57(1):107-120.

Chiarello, A. G. 1999. Effects of fragmentation of the Atlantic Forest on mammal communities in south-eastern Brazil. Biological Conservation, Amsterdam, 89:7182.

Dodson, C. H.; Dressler, R. L. et al. 1969. Biologically active compounds in orchid fragrances. Science, Washington, 164(13): 1243-1249.
Dressler, R. L. 1968a. Pollination by euglossine bees. Evolution, Tempe, 22:202-210.

1968b. Observations on orchids and euglossine bees in Panama and Costa Rica. Revista de Biologia Tropical, Costa Rica, 15(1):143-183.

1982. Biology of orchid bees (Euglossini). Annual Review of Ecology and Systematics, Palo Alto, 13:373394.

Fernandes, A. \& Bezerra, P. 1990. Estudo Fitogeográfico do Brasil. Fortaleza, Stylus Comunicações. 205p.

Garófalo, C. A.; Camillo, E. et al. 1998. Diversidade, abundância sazonal de Euglossini (Hymenoptera, Apidae) na Serra do Japi, Jundiaí, SP. In: Simpósio de Ecossistemas Brasileiros, $4^{\circ}$, Águas de Lindóia, Anais..., São Paulo, Aciesp. v.3, p.72-79.

IAPAR (Instituto Agronômico do Paraná). 1994. Cartas climáticas do estado do Paraná. Londrina. 49p.

JANZEN, D. H. 1971. Euglossine bees as long-distance pollinators of tropical plants. Science, Washington, 171:203-205.

Janzen, D. H.; DeVries, P. J. et al. 1982. Seasonal and site variation in Costa Rican euglossinae bees at chemical baits in lowland and evergreen forests. Ecology, Ithaca, 63(1):66-74.

Jesus, B. M. V. \& Garófalo, C. A. 2000. Riqueza e abundância sazonal de Euglossini (Hymenoptera, Apidae) na Mata da Virgínia, Matão, São Paulo. In: Encontro Sobre Abelhas, $4^{\circ}$, Ribeirão Preto, Anais..., Ribeirão Preto, FFCLRP-USP. v.4, p.239-245.

Katô, M.; Matsumuda, T. \& Yamashita, Z. 1952. Associative ecology of insects found in the paddy field cultivated by various planting forms. Science reports of Tohoku University, 4th. Ser. Biology, Sendai, 19:291-301.

Laroca, S. 1995. Ecologia: princípios e métodos. Petrópolis, Vozes. 197p.

Ludwig, J. A. \& Reynolds, J. F. 1988. Statistical ecology: a primer on methods and computing. New York, Interscience. $337 \mathrm{p}$.

Mendonça, F. A. 2000. A tipologia climática: gênese, características e tendências. In: STIPP, N. A. F. org. Macronozeamento ambiental da bacia hidrográfica do rio Tibagi (PR). Londrina, UEL. p.21-68.

Moldenke, A. R. 1975. Niche specialization and species diversity along a California transect. Oecologia, Berlin, 21(2):219-242.

Morato, E. F. 1998. Estudos sobre comunidades de abelhas Euglossini. In: Encontro sobre Abelhas, $3^{\circ}$, Ribeirão Preto, Anais..., Ribeirão Preto, FFCLRP-USP. v.3, p.135-143.

Morato, E. F.; Campos, L. A. O. \& Moure, J. S. 1992. Abelhas Euglossini (Hymenoptera, Apidae) coletadas na Amazônia Central. Revista Brasileira de Entomologia, São Paulo, 36(4): 767-771.

NefF, J. L. \& Simpson, B. B. 1993. Bees, pollination systems and plant diversity. In: LaSalle, J. \& Gauld, I. D. eds. Hymenoptera and biodiversity. Wallingford, C-A-B International. p.143-147.

Neves, E. L. \& Viana, B. F. 1997. Inventário da fauna de Euglossinae (Hymenoptera, Apidae) do baixo sul da Bahia, Brasil. Revista Brasileira de Zoologia, Curitiba, 14(4):831-837.

Oliveira, M. L. O. 1999. Sazonalidade e horário de atividade de abelhas Euglossinae (Hymenoptera, Apidae), em florestas de terra firme na Amazônia Central. Revista Brasileira de Zoologia, Curitiba, 16(1):83-90.

Oliveira, M. L. O. \& Campos, L. A. O. 1995. Abundância, riqueza e diversidade de abelhas Euglossinae (Hymenoptera, Apidae) em florestas contínuas de terra firme na Amazônia Central, Brasil. Revista Brasileira de Zoologia, Curitiba, 12(3):547-556.

Pearson, D. L. \& Dressler, R. L. 1985. Two-year study of male orchid bee (Hymenoptera: Apidae: Euglossini) attraction to chemical baits in lowland south-eastern Peru. Journal of Tropical Ecology, Cambridge, 1:37-54.

Peruquetti, R. C. \& Campos, L. A. O. 1997. Aspectos da biologia de Euplusia violacea (Blanchard) (Hymenoptera, Apidae, Euglossini). Revista Brasileira de Zoologia, Curitiba, 14(1):91-97. 
Peruquetti, R. C.; Campos, L. A. O. et al. 1999. Abelhas Euglossini (Apidae) de áreas de Mata Atlântica: abundância, riqueza e aspectos biológicos. Revista Brasileira de Zoologia, Curitiba, 16(Supl. 2):101-118.

Rebêlo, J. M. M. \& Cabral, A. J. M. 1997. Abelhas Euglossinae de Barreirinhas, zona do litoral da Baixada Oriental Maranhense. Acta Amazonica, Manaus, 27(2):145-152.

Rebêlo, J. M. M. \& Garófalo, C. A. 1991. Diversidade e sazonalidade de machos de Euglossini (Hymenoptera, Apidae) e preferências por iscas-odores em um fragmento de floresta no sudeste do Brasil. Revista Brasileira de Biologia, Rio de Janeiro, 51(4):787-799.

1997. Comunidades de machos Euglossini (Hymenoptera: Apidae) em matas semidecíduas do nordeste de Estado de São Paulo. Anais da Sociedade Entomológica do Brasil, Londrina, 26(2):243-255.

Rebêlo, J. M. M. \& Silva, F. S. 1999. Distribuição das abelhas Euglossini (Hymenoptera: Apidae) no Estado do Maranhão, Brasil. Anais da Sociedade Entomológica do Brasil, Londrina, 26(3):379-391.

Ricklefs, R. E.; Adams, R. M. \& Dressler, R. L. 1969. Species diversity of Euglossa in Panama. Ecology, Ithaca, 50(4):713-716.

Roubiк, D. W. 2001. Ups and downs in pollinator populations: when is there a decline? Conservation Ecology, 5(1):2. <http://www.consecol.org/vol5/iss1/art2>

Roubik, D. W. \& Ackerman, J. D. 1987. Long-term of euglossine orchid-bees (Apidae: Euglossini) in Panama. Oecologia, Berlin, 73(3):321-333.

Santos, A. M. \& Sofia, S. H. 2002. Horário de atividade de machos de Euglossinae (Hymenoptera, Apidae) em um fragmento de floresta semidecídua no norte do estado do
Paraná. Acta Scientiarum, Maringá, 24(2):375-381.

Silva, F. S. \& Rebêlo, J. M. M. 1999. Euglossine bees (Hymenoptera: Apidae) of Buriticupu, Amazonia of Maranhão, Brazil. Acta Amazonica, Manaus, 29(4):587599.

2002. Population dynamics of Euglossinae bees (Hymenoptera, Apidae) in an early second-growth forest of Cajual Island, in the State of Maranhão, Brazil. Brazilian Journal of Biology, São Carlos, 62(1):15-23.

Torrezan, J. M. 2002. Nota sobre a vegetação da bacia do rio Tibagi. In: Medri, M. E. et al. eds. A bacia do rio Tibagi. Londrina. p.103-107.

Williams, N. H. \& Dodson, C. H. 1972. Selective attraction of male euglossine bees to orchid floral fragrances and its importance in long-distance pollen flow. Evolution, Tempe, 26:84-95.

Williams, N. H. \& Whitten, W. M. 1983. Orchid floral fragrances and male euglossine bees: methods and advances in the last sesquidecade. Biological Bulletin, Stanford, 164(3):355-395.

Wittmann, D.; Radtke, R. et al. 1989. Seasonality and seasonal changes in preferences for scent baits in Eufriesea violacea in Rio Grande do Sul/Brazil. Entomologia Generalis, Stuttgart, 14(3-4):217-221.

ZAR, J. H. 1996. Biostatistical analysis. 3 ed. Englewood Cliffs, Prentice-Hall. 662p.

Zucchi, R.; Camargo, J. M. F. \& Sakagami, S. F. 1969. Biological observations on a neotropical bee, Eulaema nigrita, with a review on the biology of Euglossinae (Hymenoptera: Apoidea). A comparative study. Journal of the Faculty of Science, Hokkaido University, Zool., Sapporo, 17(2):271-380. 